Supporting Information for

\title{
Customized Energy Down-Shift Using Iridium Complexes for Enhanced Performance of Polymer Solar Cells
}

\author{
Hyun-Tak Kim, ${ }^{\dagger, 1}$ Ji Hoon Seo, ${ }^{\ddagger, l}$ Jeong Hyuk Ahn, ${ }^{\dagger, \mid}$ Myung-Jin Baek, ${ }^{\ddagger}$ Han-Don Um, ${ }^{\ddagger}$ Sojeong Lee, ${ }^{\ddagger}$ Deok-Ho \\ Roh, ${ }^{\dagger}$ Jun-Ho Yum, ${ }^{\S}$ Tae Joo Shin, ${ }^{\#}$ Kwanyong Seo, ${ }^{, \ngtr}$ and Tae-Hyuk Kwon ${ }^{*} \dagger$ \\ 'Department of Chemistry, Ulsan National Institute of Science and Technology (UNIST), Ulsan, South Korea, \\ ${ }^{\star}$ Department of Energy Engineering, Ulsan National Institute of Science and Technology (UNIST), Ulsan, South \\ Korea, ${ }^{8}$ Laboratory for Molecular Engineering of Optoelectronic Nanomaterials, École Polytechnique Fédérale de \\ Lausanne (EPFL), Station6, 1015 Lausanne, Switzerland, " UNIST Central Research Facilities \& School of Natural \\ Science, Ulsan National Institute of Science and Technology (UNIST), Ulsan, South Korea \\ *e-mail: kseo@unist.ac.kr, kwon90@unist.ac.kr
}

\section{Contents}

1. Synthetic routes of $\operatorname{Ir}(\mathrm{III})$ complexes (2)

2. Synthesis and characterizations of $\operatorname{Ir}(\mathrm{III})$ complexes (3)

3. Spectral overlap with PTB7 and exciton lifetime (10)

4. Device performances with PTB7 (13)

5. GI-WAXD for PTB7 (18)

6. AFM data (19)

7. Dipole moment calculation (20)

8. Spectral overlap with P3HT (22)

9. Device performances with P3HT (23)

10. GI-WAXD for P3HT (24)

11. Integrating sphere PL data(25)

12. Tables (26)

13. References (29) 


\section{Synthetic routes of $\operatorname{Ir}($ III) complexes}
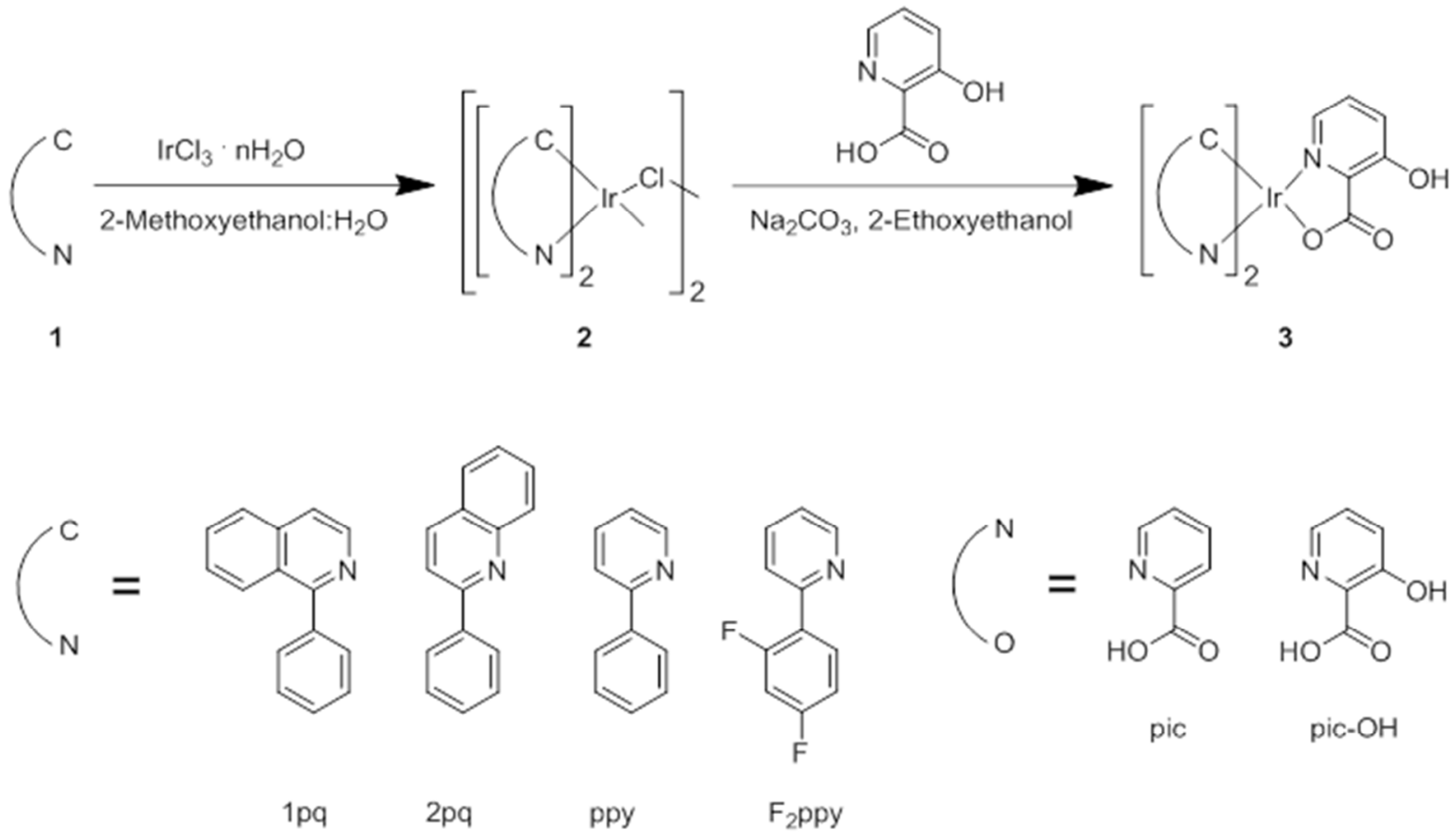

Figure S1-Synthetic routes of $\operatorname{Ir}($ III) complexes. 


\section{Synthesis and characterizations of $\operatorname{Ir}(\mathrm{III})$ complexes}

\section{Synthesis of Ir(III) complexes}

Bis[1-phenylisoquinoline- $\left.\mathrm{C}^{2}, \mathrm{~N}\right](3$-hydroxypicolinato)iridium(III)

The mixture of $\mathrm{IrCl}_{3} \cdot \mathrm{nH}_{2} \mathrm{O}(200 \mathrm{mg}, 0.67 \mathrm{mmol})$ and 1-phenylisoquinoline (412 $\left.\mathrm{mg}, 2.00 \mathrm{mmol}\right)$ was refluxed for $24 \mathrm{~h}$ in a 3:1 mixture of 2-methoxyethanol and water as a solvent. After refluxed, the materials were cooled down to room temperature and more water was added to precipitate the product. The mixture was filtered through a Büchner funnel and washed with hexane three times to get the product (355 $\mathrm{mg}, 83 \%$ yield $)^{1}$.

A mixture of compound 2 (300 mg, $0.24 \mathrm{mmol})$, 3-hydroxypicolinic acid (100 mg, $0.72 \mathrm{mmol})$ and $\mathrm{Na}_{2} \mathrm{CO}_{3}(254$ $\mathrm{mg}, 2.40 \mathrm{mmol}$ ) was refluxed for $10-12 \mathrm{~h}$ in inert condition in 2-ethoxyethanol as a solvent. After refluxed, the mixture was cooled down to room temperature and the solvent was evaporated. The mixture is dissolved in methylene chloride and then it was washed with water and dried over $\mathrm{MgSO}_{4}$. The solvent was evaporated to get crude product and it was purified by column chromatography on silica gel. At a result, the product was provided (238 $\mathrm{mg}, 67 \%$ yield $)^{2}$. The characterization data of this product is in Supporting Information.

Other Ir(III) complexes ((2pq) Irpic-OH (Orange), (ppy) $)_{2}$ Irpic-OH (Green), FIrpic-OH (Blue)) were synthesized with similar procedure with Red in the above. 


\section{Bis[1-phenylisoquinoline-C ${ }^{2}$,N](3-hydroxypicolinato)iridium(III)}

FT-IR (KBr, cm $\left.{ }^{-1}\right): 3440$ (w, -OH), 1635 (s, C=O), 1598 (m), 1462 (m), 1380 (w), 1313 (m).

${ }^{1} \mathrm{H}$ NMR (400 MHz, $\left.\mathrm{CDCl}_{3}\right): \delta 13.836(\mathrm{~s}, 1 \mathrm{H}), 8.961(\mathrm{~m}, 2 \mathrm{H}), 8.658(\mathrm{~d}, J=6.4 \mathrm{~Hz}, 1 \mathrm{H}), 8.257$ (d, J=7.6 Hz, 1H), $8.194(\mathrm{~d}, J=7.6 \mathrm{~Hz}, 1 \mathrm{H}), 7.937(\mathrm{~m}, 1 \mathrm{H}), 7.880(\mathrm{~m}, 1 \mathrm{H}), 7.734(\mathrm{~m}, 4 \mathrm{H}), 7.517$ (d, J=6.8 Hz, 1H), 7.450 ( d, J=6.4 Hz, 1H), $7.367(\mathrm{~m}, 1 \mathrm{H}), 7.320(\mathrm{~d}, J=6.4 \mathrm{~Hz}, 1 \mathrm{H}), 7.156(\mathrm{~m}, 1 \mathrm{H}), 7.097$ (m, 1H), 7.007 (m, 1H), $6.942(\mathrm{~m}, 1 \mathrm{H}), 6.774(\mathrm{~m}$, 1H), 6.715 (m, 1H), 6.491 (d, $J=6.8 \mathrm{~Hz}, 1 \mathrm{H}), 6.222$ (d, $J=6.8 \mathrm{~Hz}, 1 \mathrm{H})$.

${ }^{13} \mathrm{C}$ NMR (100 MHz, $\left.\mathrm{CDCl}_{3}\right): \delta 177.50,170.17,168.23,160.53,151.77,150.40,146.00,145.76,140.71,140.22$, 139.72, 137.06, 137.00, 134.85, 133.05, 131.11, 131.01, 130.16, 130.06, 129.96, 129.61, 128.11, 128.02, 127.56, 127.36, 127.07, 126.47, 126.42, 126.31, 126.17, 121.45, 120.83, 120.81, 120.70.

Exact mass: 739.1447 , found mass: 739.1450 . 


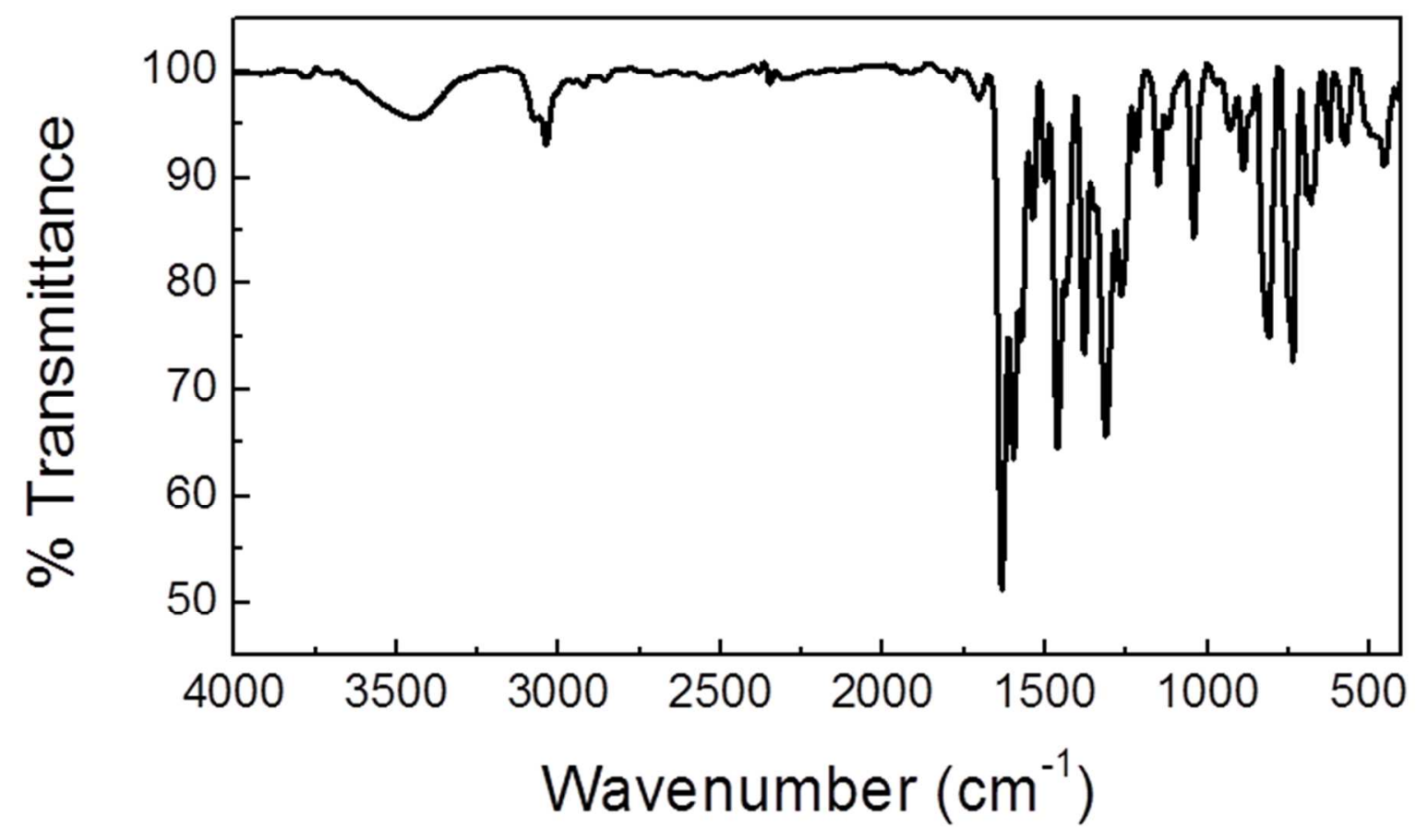

Figure S2-FT-IR spectrum of (1pq) ${ }_{2}$ Irpic-OH (Ir-Red) in $\mathrm{KBr}$ pellet. 


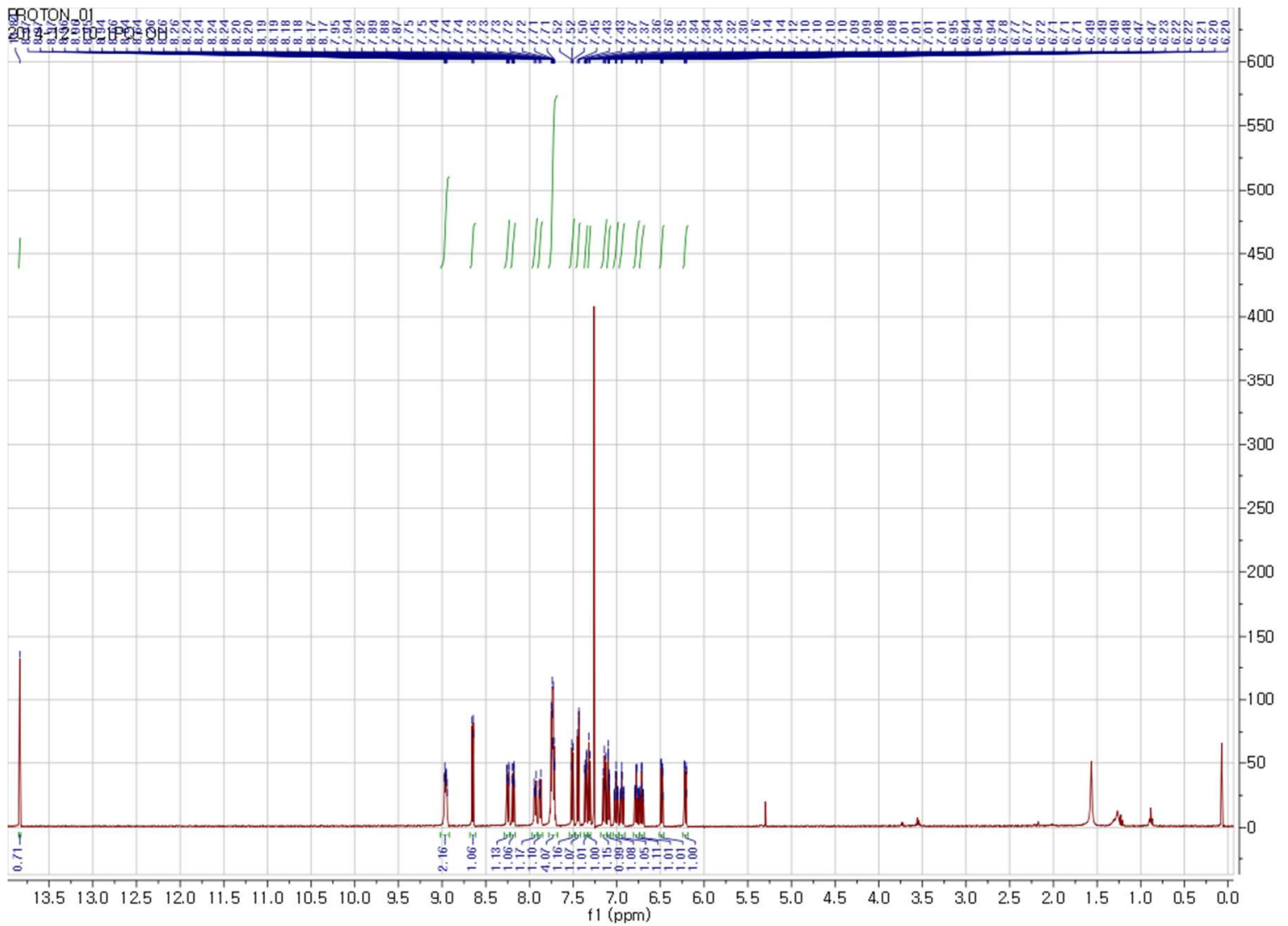

Figure S3- ${ }^{1} \mathrm{H}$ NMR of $(1 \mathrm{pq})_{2}$ Irpic-OH (Ir-Red) in $\mathrm{CDCl}_{3}$. 


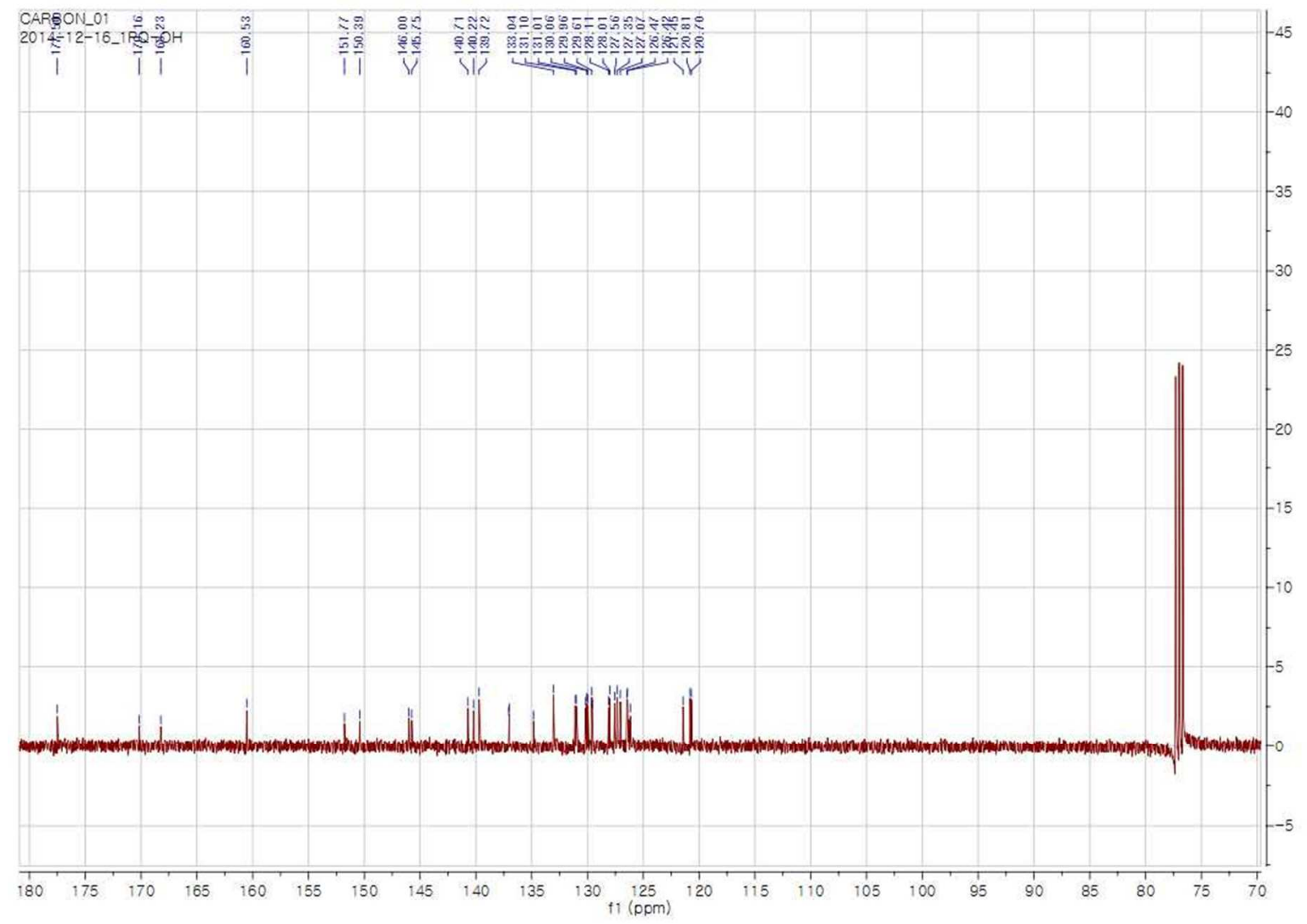

Figure S4- ${ }^{13} \mathrm{C}$ NMR of $(1 \mathrm{pq})_{2}$ Irpic-OH (Ir-Red) in $\mathrm{CDCl}_{3}$. 


\section{(2pq) $)_{2}$ Irpic-OH (Ir-Orange)}

FT-IR (KBr, $\left.\mathrm{cm}^{-1}\right): 3441$ (w, -OH), 1636 (s, C=O), 1601 (s), 1461 (s), 1330 (m).

${ }^{1} \mathrm{H}$ NMR $\left(400 \mathrm{MHz}, \mathrm{CDCl}_{3}\right): \delta 13.415(\mathrm{~s}, 1 \mathrm{H}), 8.646(\mathrm{~d}, J=8.8 \mathrm{~Hz}, 1 \mathrm{H}), 8.210(\mathrm{~d}, J=16.8 \mathrm{~Hz}, 1 \mathrm{H}), 8.189(\mathrm{~d}, J=16.8$ Hz, 1H), 8.107 (m, 2H), $7.951(\mathrm{dd}, J=8 \mathrm{~Hz}, 1 \mathrm{H}), 7.835$ (dd, $J=8 \mathrm{~Hz}, 1 \mathrm{H}), 7.741(\mathrm{~m}, 2 \mathrm{H}), 7.554(\mathrm{~m}, 1 \mathrm{H}), 7.475(\mathrm{~m}$, 2H), $7.358(\mathrm{~m}, 2 \mathrm{H}), 7.12(\mathrm{~m}, 2 \mathrm{H}), 7.099(\mathrm{~m}, 1 \mathrm{H}), 6.987(\mathrm{~m}, 1 \mathrm{H}), 6.953(\mathrm{~m}, 1 \mathrm{H}), 6.862(\mathrm{~m}, 1 \mathrm{H}), 6.775(\mathrm{~m}, 1 \mathrm{H})$, $6.666(\mathrm{~m}, 1 \mathrm{H}), 6.286(\mathrm{dd}, J=6.8 \mathrm{~Hz}, 1 \mathrm{H})$.

${ }^{13} \mathrm{C}$ NMR (100 MHz, $\left.\mathrm{CDCl}_{3}\right): \delta 176.26,170.87,169.11,159.63,149.46,149.17,148.40,147.78,146.72,145.71$, $138.82,138.65,137.10,136.10,135.78,134.79,131.81,129.94,129.83,129.63,128.81,128.74,127.89,127.80$, $127.34,127.08,126.74,126.17,126.10,126.03,125.75,125.04,122.18,121.28,117.18,116.43$.

Exact mass: 739.1447 , found mass: 739.1450 .

\section{(ppy) $)_{2}$ Irpic-OH (Ir-Green)}

FT-IR (KBr, cm $\left.{ }^{-1}\right): 3423$ (w, -OH), 1632 (s, C=O), 1601 (m), 1471 (s), 1315 (m), 1256 (m), 1249 (m)

${ }^{1} \mathrm{H}$ NMR (400 MHz, $\mathrm{CDCl}_{3}$ ): $\delta$ 13.812. (s,1H), 8.717 (m, 1H), 7.894 (d, J=17.2 Hz, 1H), 7.874 (d, J=16.8 Hz, 1H), 7.747 (m, 2H), 7.605 (m, 2H), $7.520(\mathrm{~m}, 1 \mathrm{H}), 7.381(\mathrm{~m}, 1 \mathrm{H}), 7.253(\mathrm{~m}, 1 \mathrm{H}), 7.184(\mathrm{~m}, 2 \mathrm{H}), 6.987$ (m, 1H), $6.941(\mathrm{~m}$, 1H), $6.889(\mathrm{~m}, 1 \mathrm{H}), 6.807(\mathrm{~m}, 1 \mathrm{H}), 6.770(\mathrm{~m}, 1 \mathrm{H}), 6.374$ (dd, $J=7.6 \mathrm{~Hz}, 1 \mathrm{H}), 6.200$ (dd, $J=7.6 \mathrm{~Hz}, 1 \mathrm{H})$.

${ }^{13} \mathrm{C}$ NMR $\left(100 \mathrm{MHz}, \mathrm{CDCl}_{3}\right): \delta 177.53,169.14,167.51,160.56,148.81,148.57,148.10,145.94,144.17,143.88$, $139.70,137.33,137.18,134.84,132.53,132.40,129.95,129.67,129.57,126.44,124.28,124.13,122.29,122.14$, $121.77,121.17,119.03,118.53$.

Exact mass: 639.1134, found mass: 639.1136.

\section{(F $F_{2}$ py)Irpic-OH (Ir-Blue)}

FT-IR (KBr, cm $\left.{ }^{-1}\right): 3432$ (w, -OH), 1639 (m, C=O), 1601 (s), 1477 (m), 1404 (m), 1313 (m), 1249 (m).

${ }^{1} \mathrm{H}$ NMR (400 MHz, $\left.\mathrm{CDCl}_{3}\right): \delta 13.569(\mathrm{~s}, 1 \mathrm{H}), 8.674(\mathrm{~m}, 1 \mathrm{H}), 8.314(\mathrm{~m}, 1 \mathrm{H}), 8.257(\mathrm{~d}, J=8.4 \mathrm{~Hz}, 1 \mathrm{H}), 7.821(\mathrm{~m}$, 
2H), $7.480(\mathrm{~m}, 1 \mathrm{H}), 7.446(\mathrm{~m}, 1 \mathrm{H}), 7.263(\mathrm{~m}, 2 \mathrm{H}), 7.243(\mathrm{~m}, 1 \mathrm{H}), 7.047(\mathrm{~m}, 1 \mathrm{H}), 6.505(\mathrm{~m}, 1 \mathrm{H}), 6.440(\mathrm{~m}, 1 \mathrm{H})$, $5.793(\mathrm{~m}, 1 \mathrm{H}), 5.586(\mathrm{~m}, 1 \mathrm{H})$.

${ }^{13} \mathrm{C}$ NMR $\left(100 \mathrm{MHz}, \mathrm{CDCl}_{3}\right): \delta 177.42,160.68,148.54,148.00,139.56,138.42,138.31,134.30,129.97,127.26$, $123.42,123.23,122.91,122.72,122.61,122.47,114.60,114.57,114.42,114.39,98.61,98.34,98.12,97.85,97.59$.

Exact mass: 711.0757, found mass: 711.0755 . 


\section{Spectral overlap of Ir(III) complexes and PTB7}

a

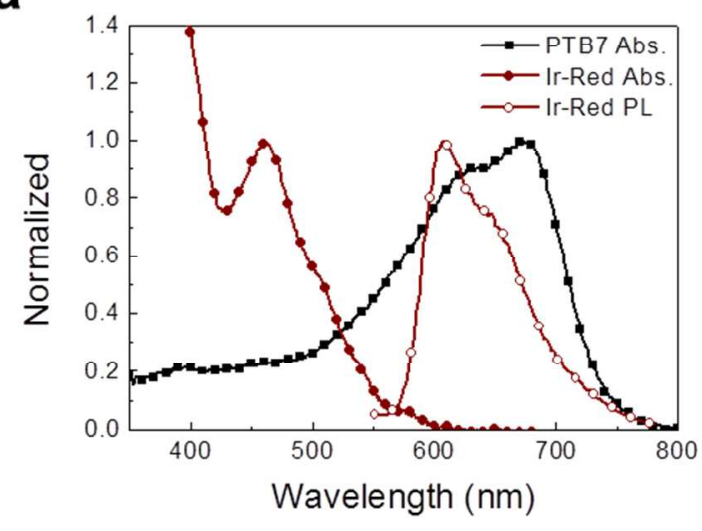

C

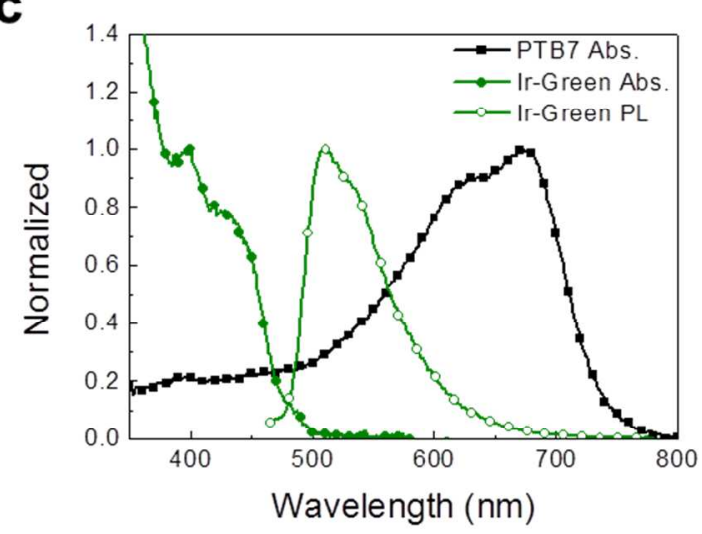

b

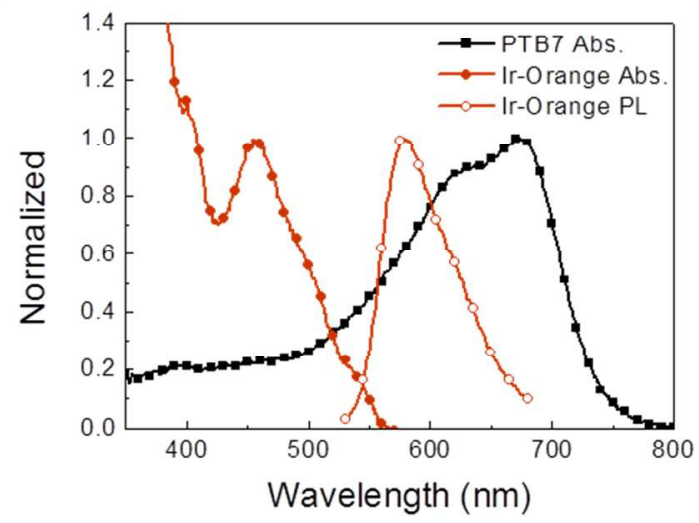

d

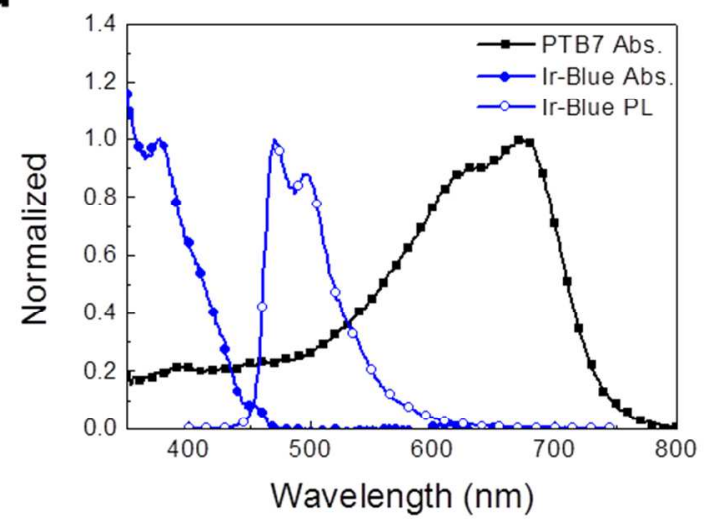

Figure S5-Overlap between emission of $\operatorname{Ir}($ III) complexes and absorption of PTB7. Absorption spectra of PTB7, absorption and emission spectra of (a) Ir-Red, (b) Ir-Orange, (c) Ir-Green, and (d) Ir-Blue. The excitation wavelengths of Ir-Blue, Ir-Green, Ir-Orange, and Ir-Red are at 376, 400, 455, and $462 \mathrm{~nm}$ which are MLCT region of each $\operatorname{Ir}(I I I)$ complexes. 


\section{Absorption of PTB7:PC ${ }_{71}$ BM:Ir(III) complexes blended films}

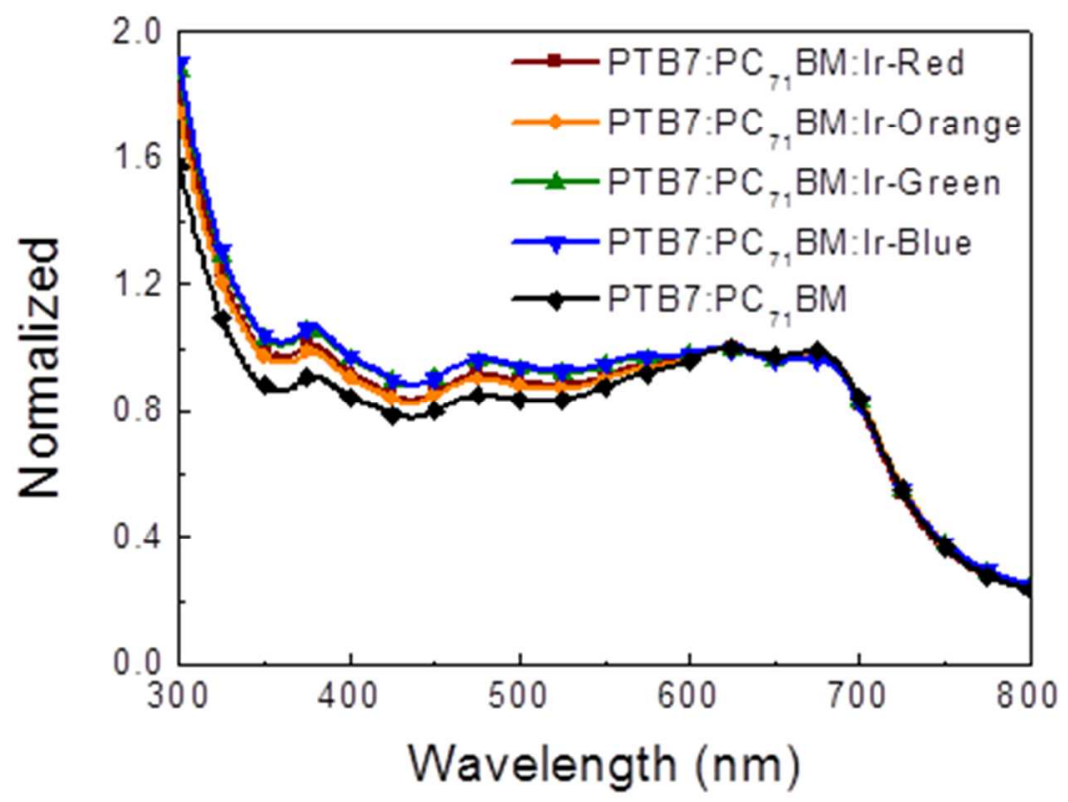

Figure S6-Absorptions of PTB7:PC ${ }_{71} \mathrm{BM}$ blended films with and without Ir(III) complexes (10 wt\%). Absorption spectra of PTB7:PC ${ }_{71}$ BM blended films with Ir-Red, Ir-Orange, Ir-Green, Ir-Blue, and without Ir(III) complexes. 


\section{Spectral overlap with PTB7 and exciton lifetime}

a

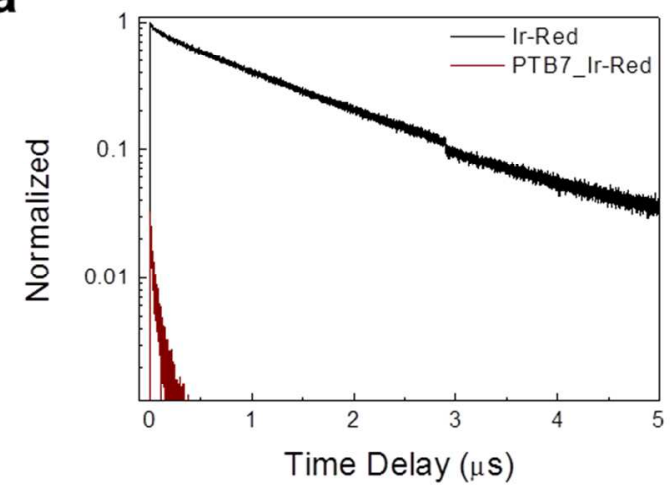

C

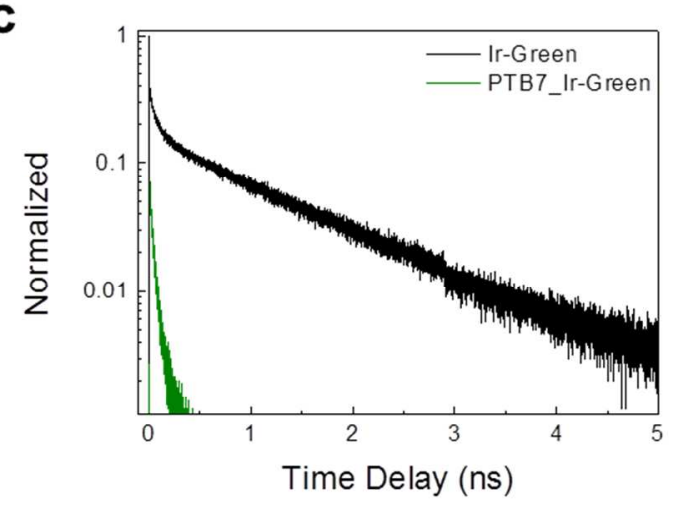

b

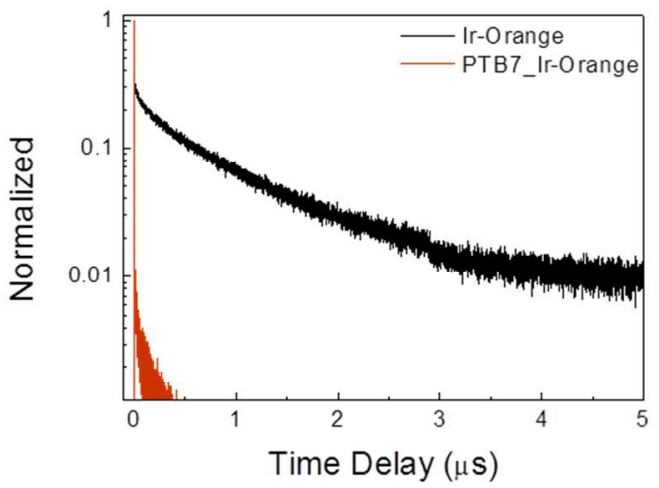

d

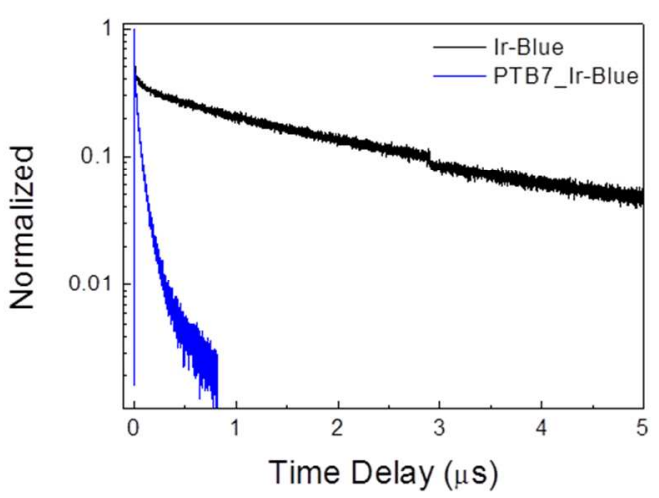

Figure S7-Exciton lifetime of pristine Ir(III) complexes film and PTB7 blended film. Black line is transient PL spectra of (a) Ir-Red, (b) Ir-Orange, (c) Ir-Green, and (d) Ir-Blue and red, orange, green, and blue line is transient PL spectra of PTB7 blended film with (a) Ir-Red, (b) Ir-Orange, (c) Ir-Green, and (d) Ir-Blue, respectively. The excitation wavelengths of Ir-Blue, Ir-Green, Ir-Orange, and Ir-Red are at 376, 400, 455, and $462 \mathrm{~nm}$ which are MLCT region of each $\operatorname{Ir}(I I I)$ complexes. 


\section{Device performances with PTB7}

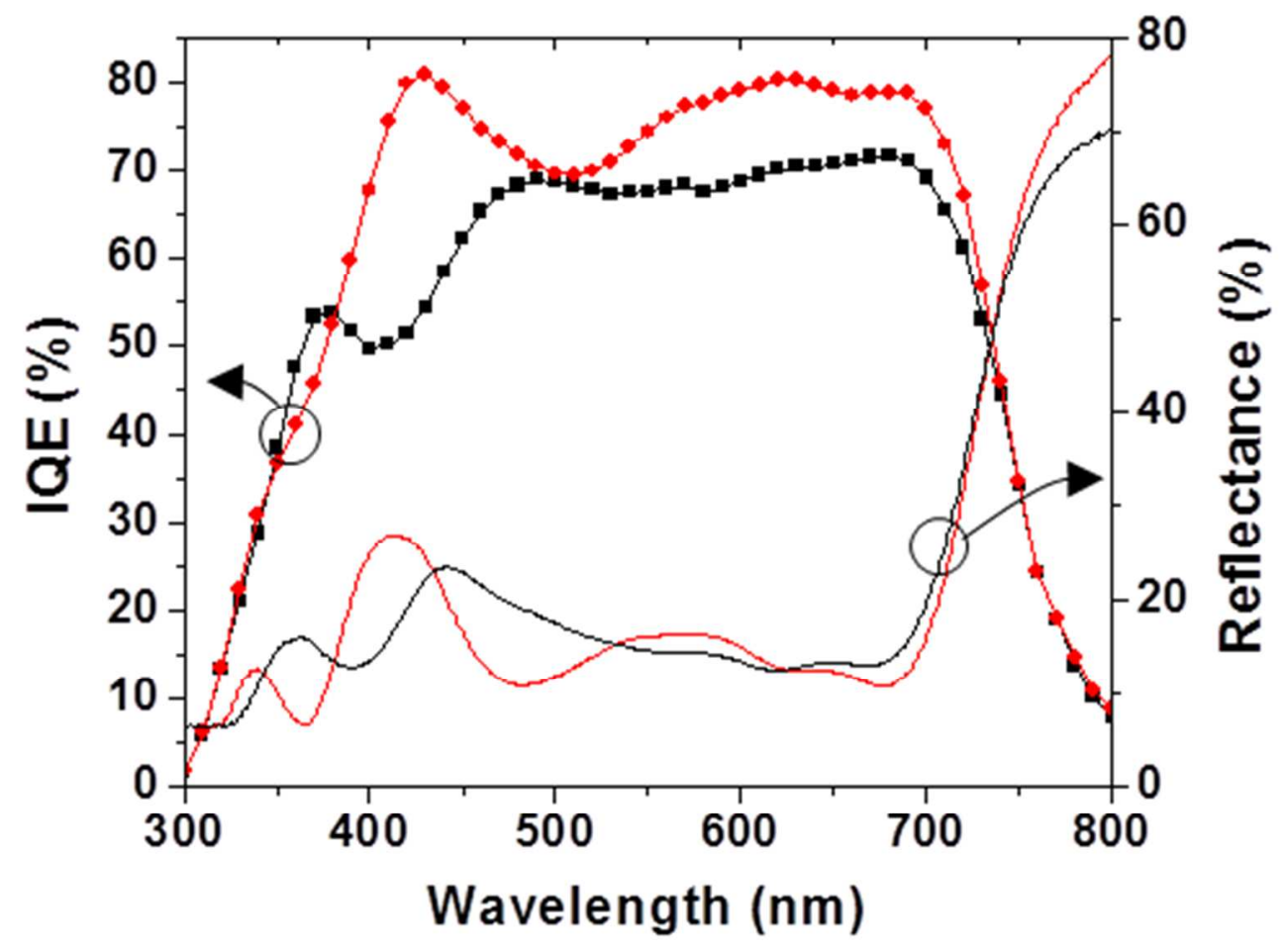

Figure S8-Device performances, IQE and reflectance data. IQE spectra of the PTB7:PC ${ }_{71} B M$ PSC device with (red circle with line) and without (black square with line) $10 \mathrm{wt} \%$ Ir-Orange. Reflectance of the PTB7:PC 71 BM PSC device with (red solid line) and without (black solid line) $10 \mathrm{wt} \%$ Ir-Orange. 
a

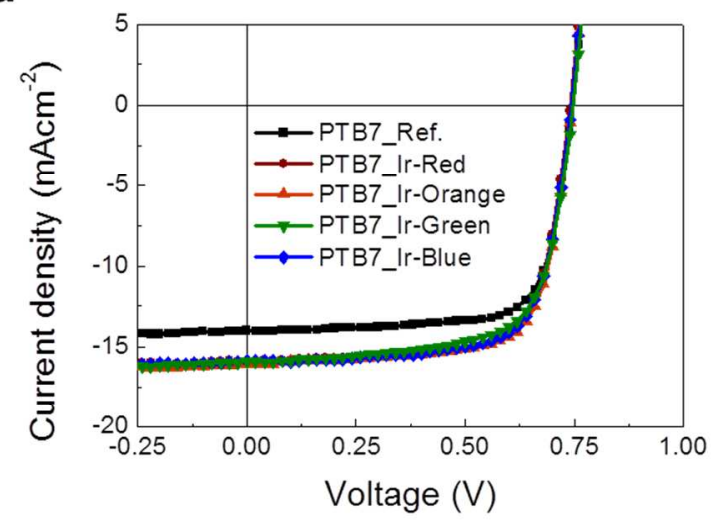

b

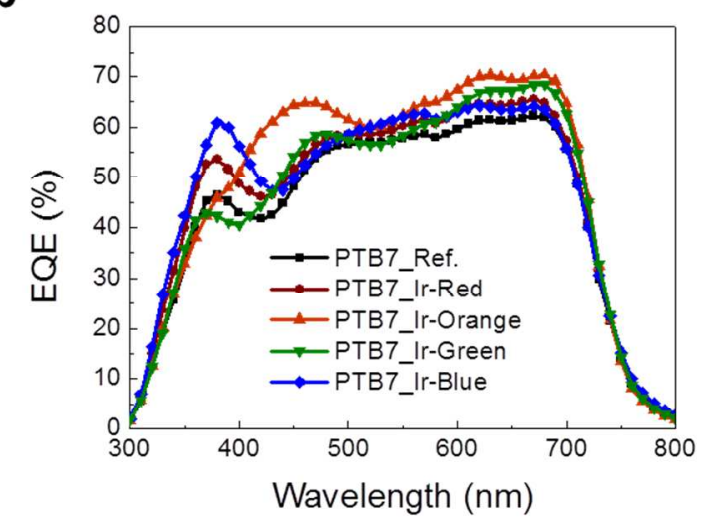

Figure S9-Device performances, J-V curves and EQE data. a, J-V curves of the PTB7:PC ${ }_{71} B M$ device with and without $10 \mathrm{wt} \%$ of various $\operatorname{Ir}(\mathrm{III})$ complexes under $1000 \mathrm{Wm}^{-2}$ and $\mathbf{b}$, EQE data of devices with and without 10 wt\% various $\operatorname{Ir}(\mathrm{III})$ complexes. 


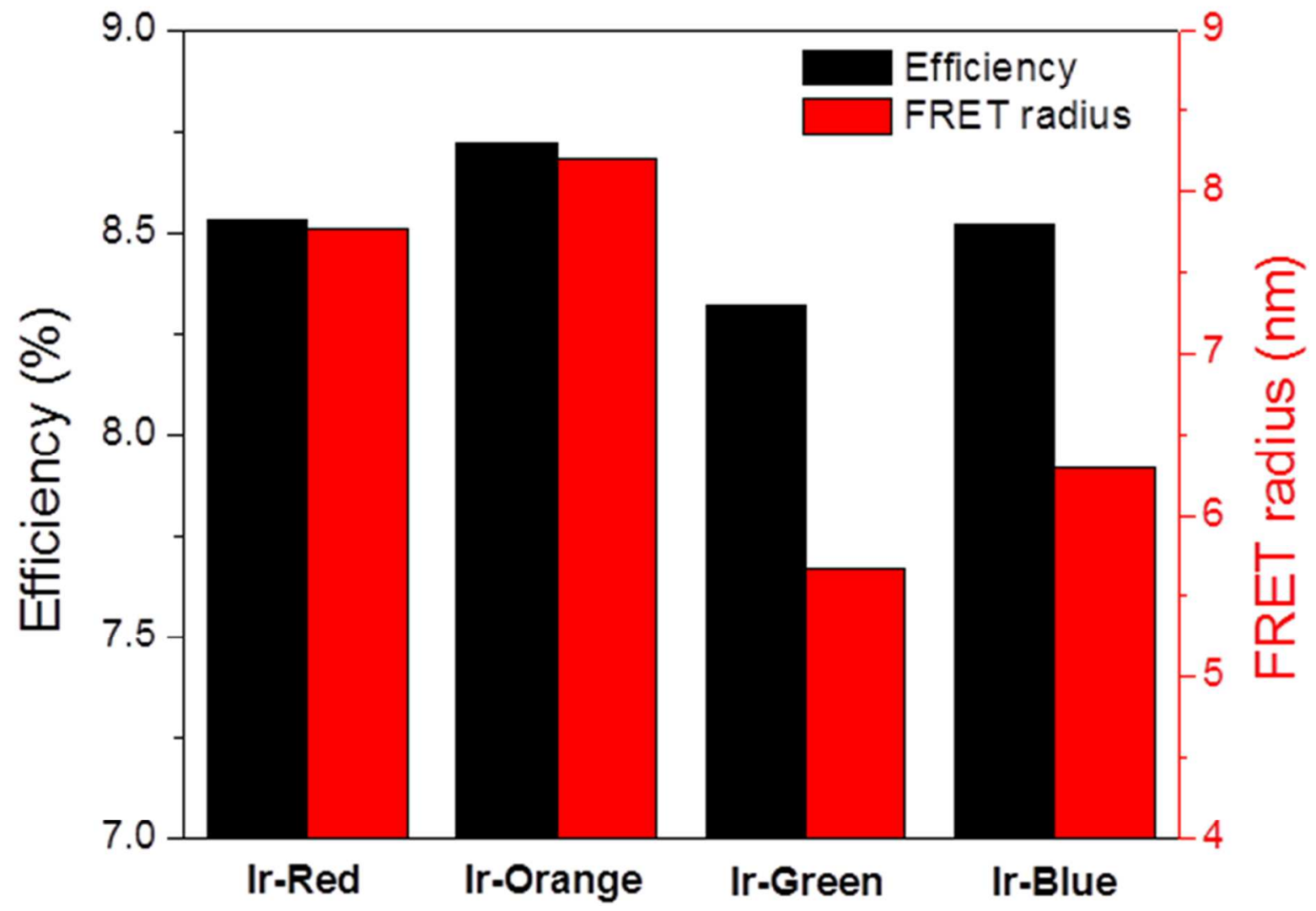

Figure S10-Efficiency of devices with Ir(III) complexes (black line) and FRET radius (red line). The trends of two factors are well matched. Thus, this graph shows that the efficiencies are very closely related with FRET radius. 
a

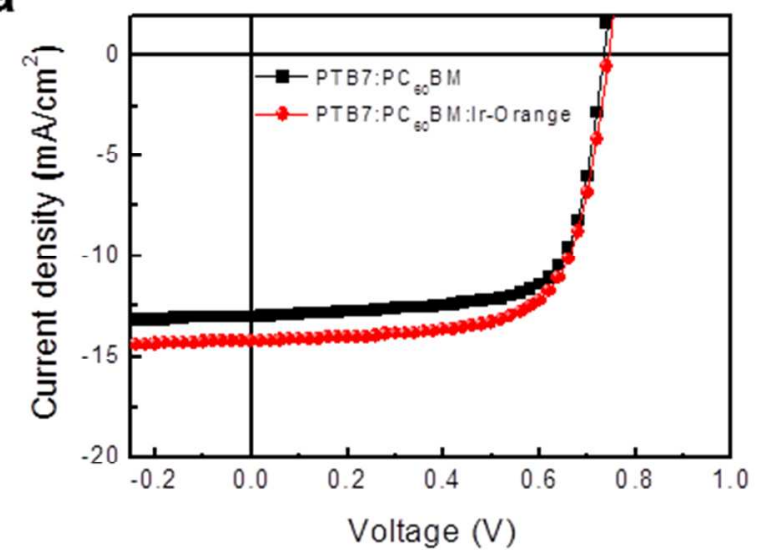

b

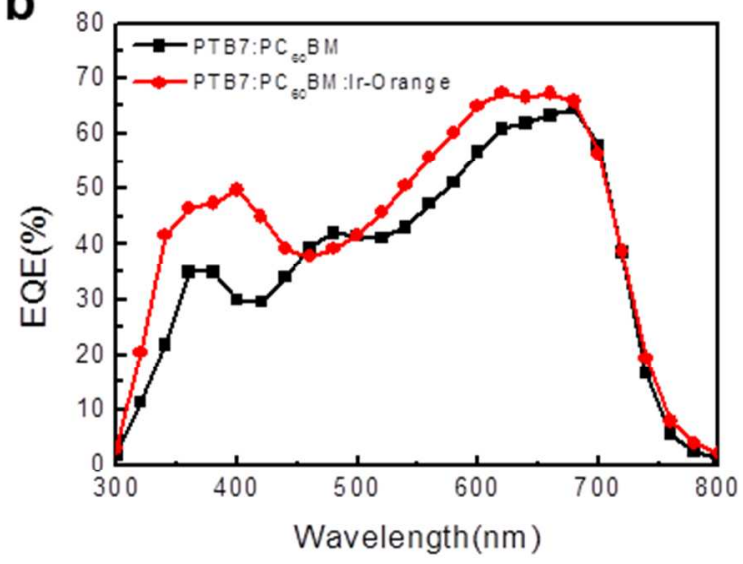

Figure S11-Device performances, J-V curves and EQE data of $\mathbf{P C}_{60} \mathrm{BM}$ based devices. a, J-V curves of the PTB7:PC ${ }_{60} \mathrm{BM}$ device with and without $10 \mathrm{wt} \%$ of Ir-Orange under $1000 \mathrm{Wm}^{-2}$ and $\mathrm{b}$, EQE data of devices with and without 10 wt\% of Ir-Orange. 

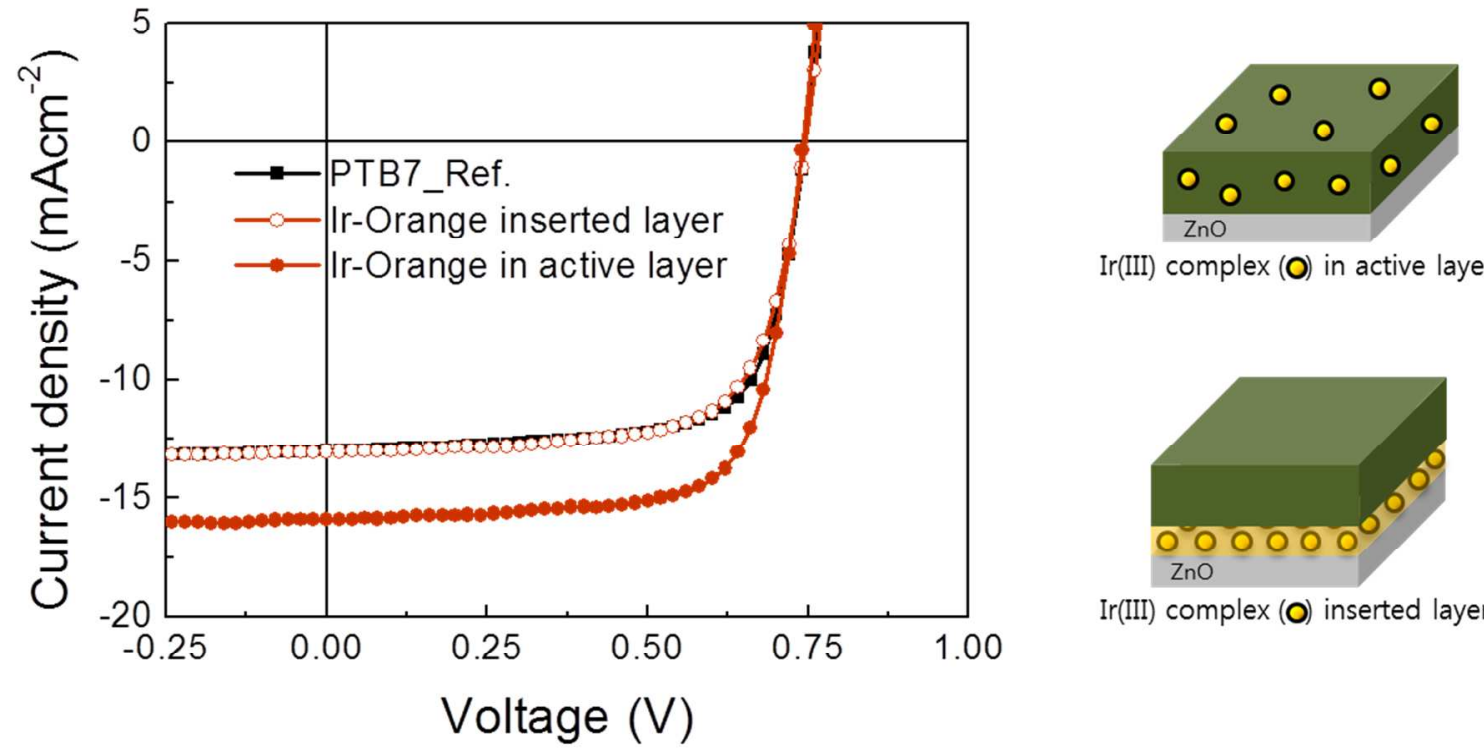

Ir(III) complex (O) in active layer

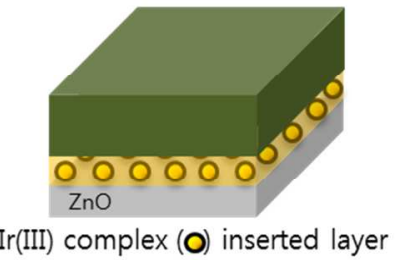

Figure S12-Device performances, J-V curves of reference, with Orange inserted layer, and with Orange in active layer. The device with inserted layer was fabricated. The Ir-Orange was spin-coated between $\mathrm{ZnO}$ and active layer instead of blending with PTB7 in active layer. Due to there is no energy transfer between Ir-Orange and PTB7 the $J_{S C}$ of inserted layer device is not enhanced. 


\section{GI-WAXD for PTB7}
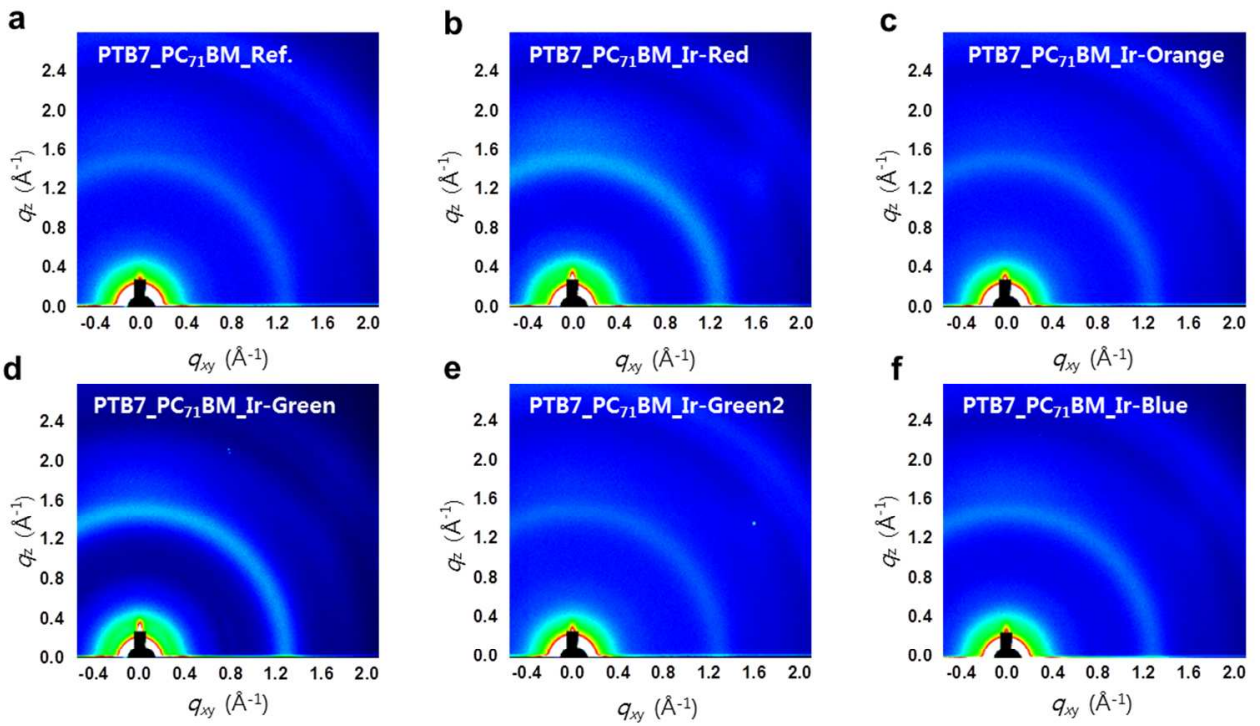

g

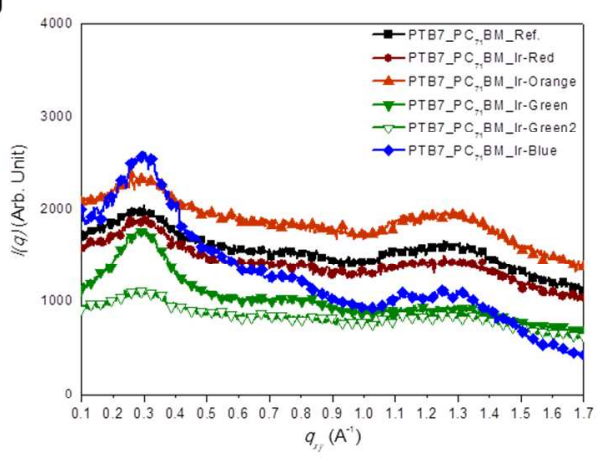

h

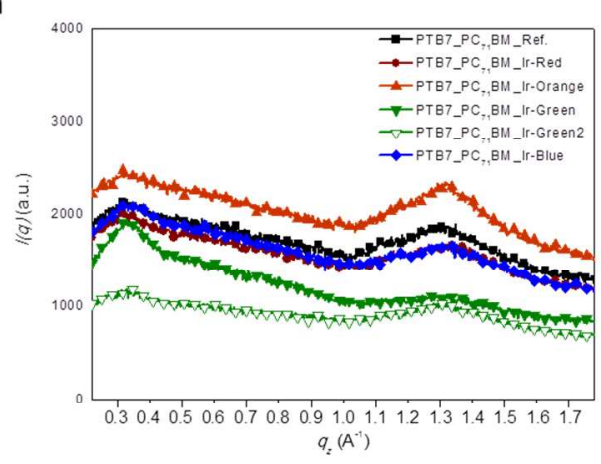

i
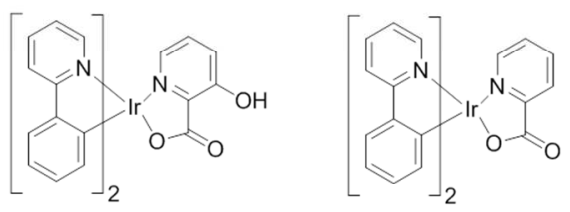

(ppy) $)_{2}$ Irpic-OH

"Ir-Green"

(ppy) $)_{2}$ Irpic

"Ir-Green2"

Figure S13-2D GI-WAXD patterns and line-cut profiles of PTB7:Ir(III) complex:PC71BM blended films on ZnO modified Si substrate. a-h, 2D GI-WAXD patterns of PTB7:PC ${ }_{71}$ BM (1:1.5) (a), PTB7:Ir-Red:PC ${ }_{71}$ BM (1:0.1:1.5) (b), PTB7:Ir-Orange:PC ${ }_{71}$ BM (1:0.1:1.5) (c), PTB7:Ir-Green:PC ${ }_{71}$ BM (1:0.1:1.5) (d), PTB7:Ir-Green2:PC ${ }_{71} B M(1: 0.1: 1.5)$ (e), and PTB7:Ir-Blue:PC ${ }_{71} B M$ (1:0.1:1.5) (f). GI-WAXD line-cut profiles of PTB7:Ir(III) complex:PC ${ }_{71} B M$ system (in-plane) and (g) PTB7:Ir(III) complex:PC ${ }_{71}$ BM system (out-of-plane) (h). i, structure of Ir-Green and Ir-Green2 
AFM data

a

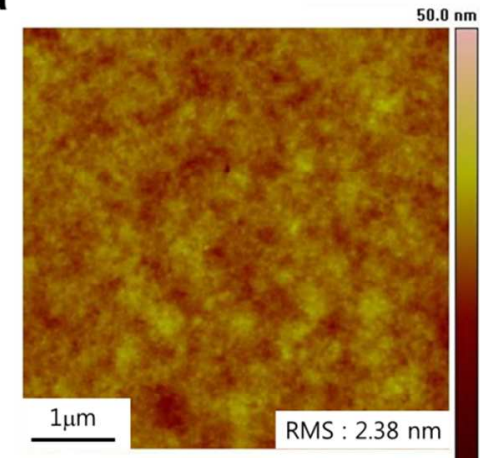

b

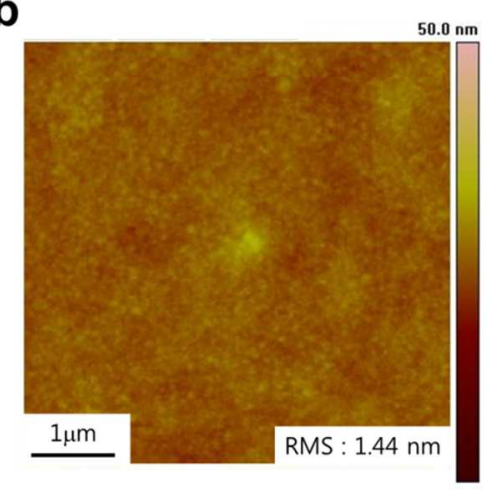

C

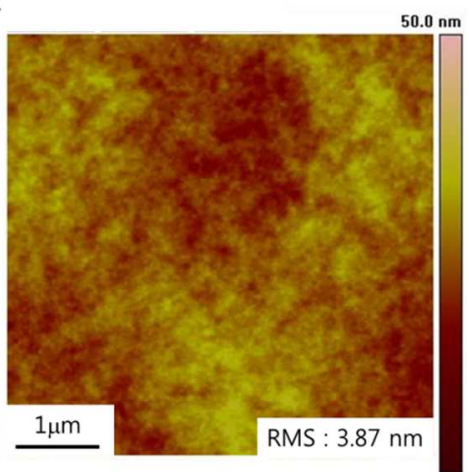

Figure S14-2D AFM images of PTB7:PC ${ }_{71} B M$ blended films with and without $\operatorname{Ir}(I I I)$ complexes. a, 2D AFM image of PTB7:PC ${ }_{71} B M$ blended film, $b, 2 D$ AFM image of PTB7:PC ${ }_{71} B M$ blended film with Ir-Green, $c, 2 D$ AFM image of PTB7:PC ${ }_{71} B M$ blended film with Ir-Green2.

The conditions for preparing the films for obtaining the AFM images (PTB7/Ir-Green, PTB7/Ir-Green2, and PTB7 without the $\operatorname{Ir}(\mathrm{III})$ complex) were the same as those for device fabrication, so as to allow for an accurate comparison. In the phase images, PTB7/Ir-Green exhibited the smallest rms value $(1.44 \mathrm{~nm})$ as well as the most homogenous distributions, followed by pristine PTB7 $(2.38 \mathrm{~nm})$ and PTB7/Ir-Green2 $(3.87 \mathrm{~nm})$. In other words, the AFM data also confirmed that the amphiphilic nature of the $\operatorname{Ir}(\mathrm{III})$ complexes enhanced the miscibility as well as the crystallinities of PTB7 and $\mathrm{PC}_{71} \mathrm{BM}$. 


\section{Dipole moment calculation}
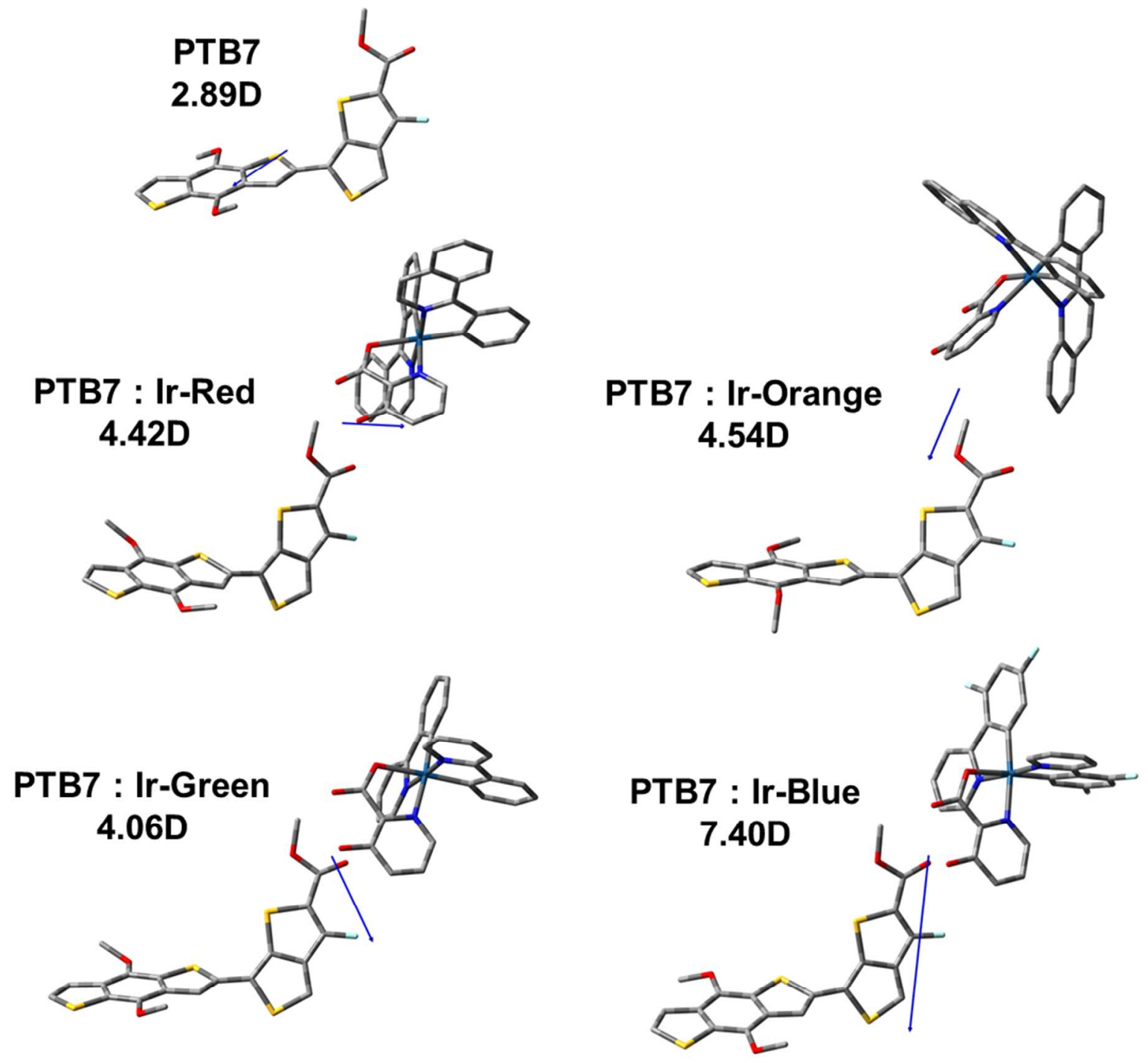

Figure S15-Semi-empirical calculation data by PM6 function. The dipole moments of only PTB7, PTB7:Ir-Red, PTB7:Ir-Orange, PTB7:Ir-Green, and PTB7:Ir-Blue optimized incorporation geometry.

We also investigated whether the Ir(III) complexes enhanced the dipole moments of the Ir (III) complexesincorporating PTB7 molecules. An increase in the dipole moment would contribute to the alignment of PTB7 as well as to its crystallinity. The films formed by blending $\mathrm{PTB} 7$ and $\mathrm{PC}_{71} \mathrm{BM}$ with Ir-Blue exhibited the highest dipole moment and nanocrystallite sizes. Therefore, The device based on Ir-Blue exhibited a PCE (8.52\%) as high as that of 
the device based on Ir-Red (8.53\%), even though Ir-Blue has a lower FRET radius (5.7 $\mathrm{nm})$ than that of Ir-Red (7.8 $\mathrm{nm}$ ). Interestingly, after the addition of $10 \mathrm{wt} \%$ Ir-Blue to the PTB7 films (PTB7:Blue $10 \mathrm{wt} \%$ ), a new scattering peak was observed at $q_{y}$ of $0.712 \pm 0.003 \AA^{-1}$ in between the scattering related to the PTB7 layers, instead of individual peaks, indicating the incorporation of the thiophene spacers of PTB7 and the fluorine substituents of IrBlue at the molecular level ${ }^{3}$. The formation of cocrystals would facilitate energy transfer between PTB7 and the Ir(III) complexes, since the rate constant for triplet-singlet energy transfer is proportional to $(1 / \mathrm{r})^{6}$, where $\mathrm{r}$ is the distance between PTB7 and the $\operatorname{Ir}(\mathrm{III})$ complex in question. In addition, the growth of larger PTB7 and $\mathrm{PC}_{71} \mathrm{BM}$ nanocrystallites would improve charge transport within the PTB7 and $\mathrm{PC}_{71} \mathrm{BM}$ domains ${ }^{4}$. 
Spectral overlap with P3HT

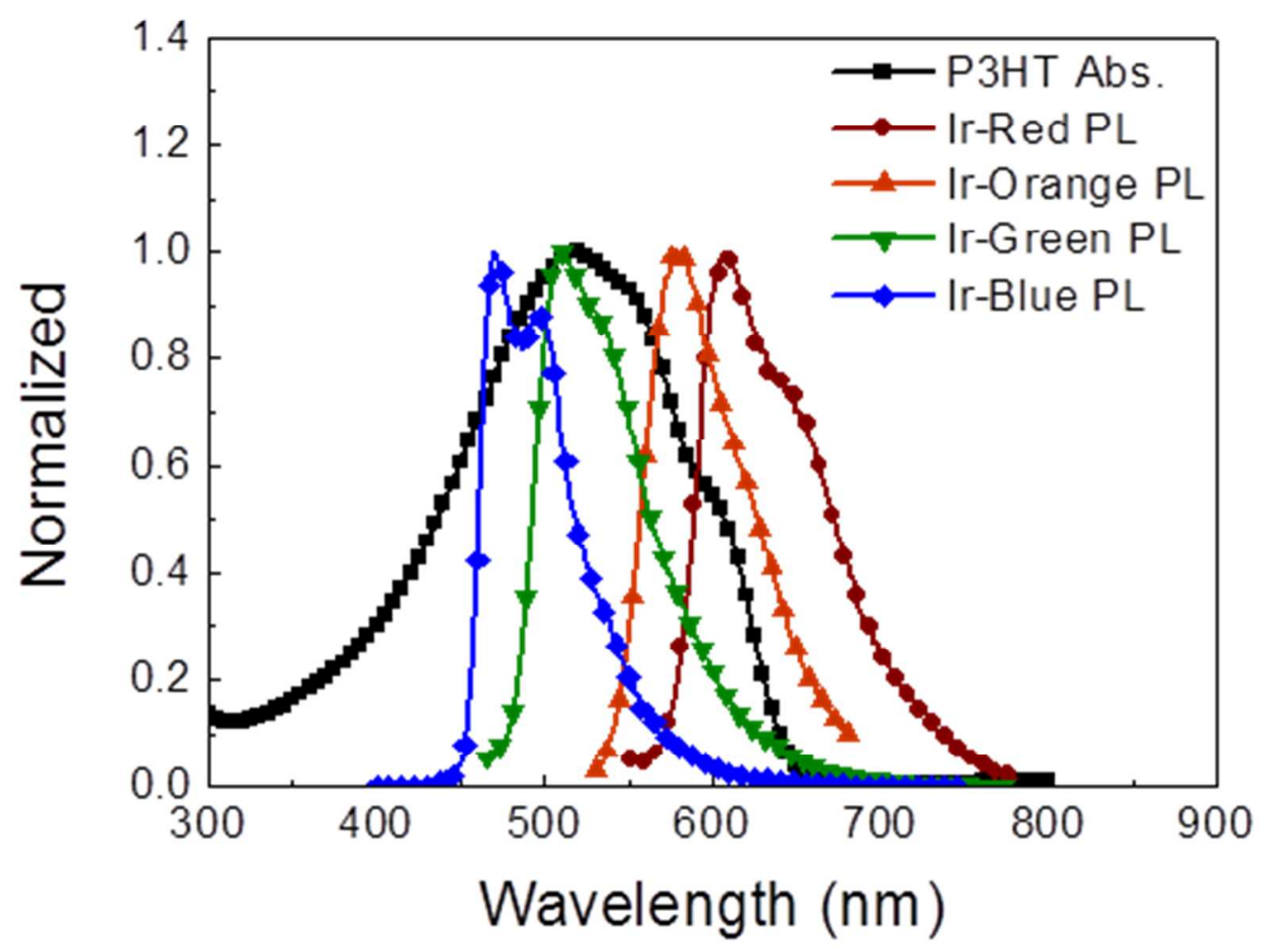

Figure S16-Overlap between emission of Ir(III) complexes and absorption of P3HT. 
Device performances with P3HT

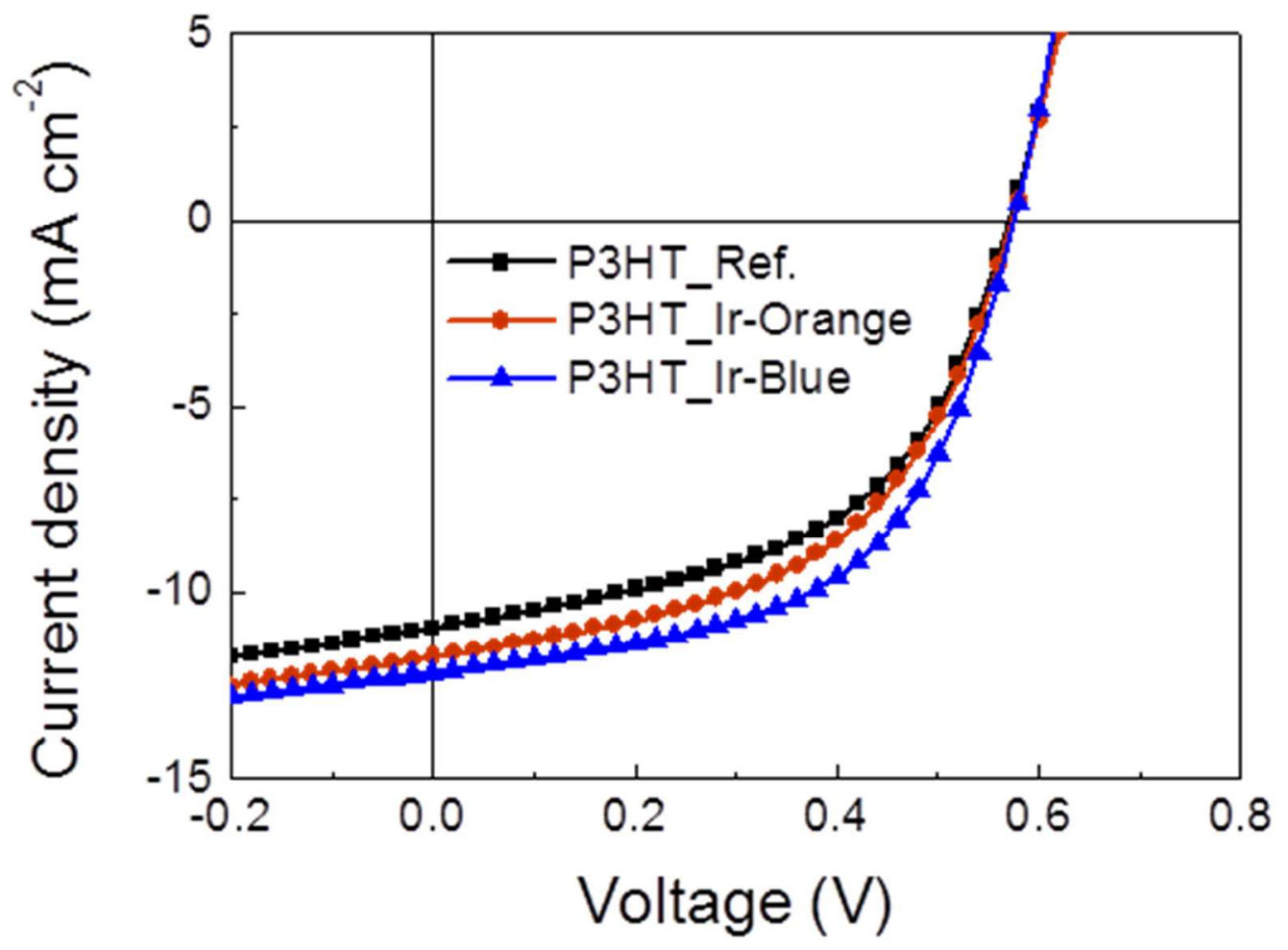

Figure S17-Device performance, J-V curves of P3HT reference, Ir-Orange in active layer and Ir-Blue in active layer. 


\section{GI-WAXD for P3HT}
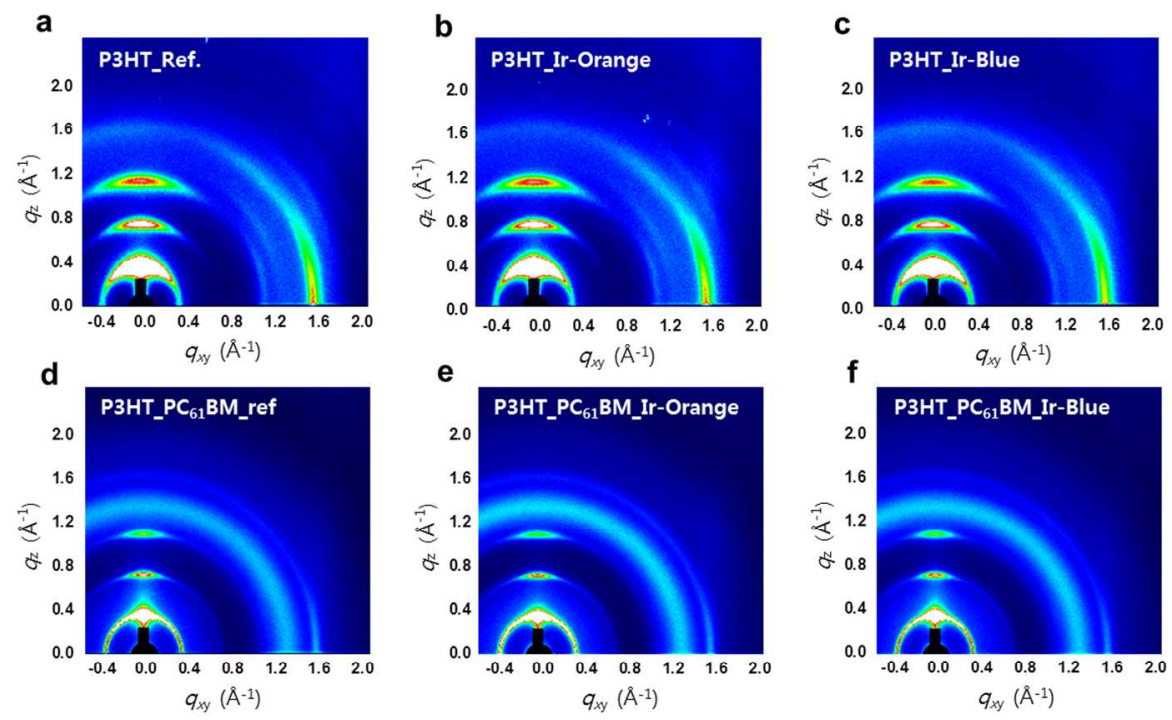

g

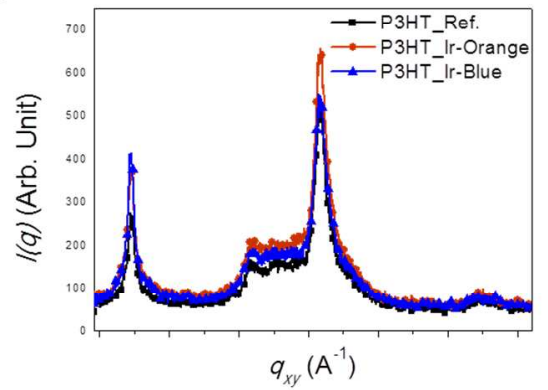

h
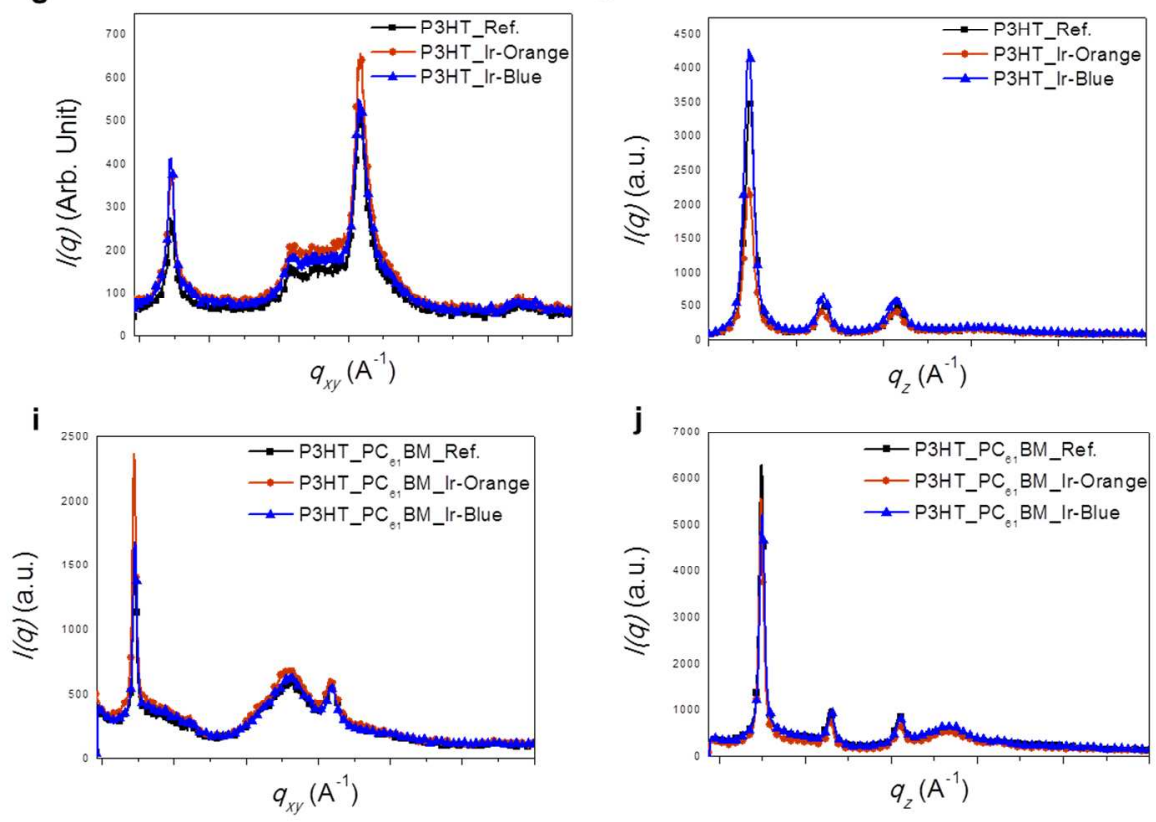

Figure S18-2D GI-WAXD patterns and line-cut profiles of P3HT:Ir(III) complexes blended films and P3HT:Ir(III) complexes:PC ${ }_{61}$ BM on PEDOT:PSS modified Si substrate. a-j, 2D GI-WAXD patterns of P3HT (a), P3HT:Ir-Orange

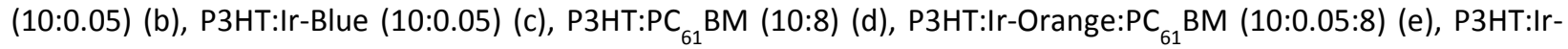
Blue:PC ${ }_{61}$ BM (10:0.05:8) (f). GI-WAXD line-cut profiles of P3HT:Ir(III) complexes system (in-plane) (g), P3HT:Ir(III) complexes system (out-of-plane) (h), P3HT:Ir(III) complexes:PC ${ }_{61} B M$ system (in-plane) (i), and P3HT:Ir(III) complexes:PC ${ }_{61}$ BM system (out-of-plane) (j). 
Integrating sphere PL data

Normal PL data

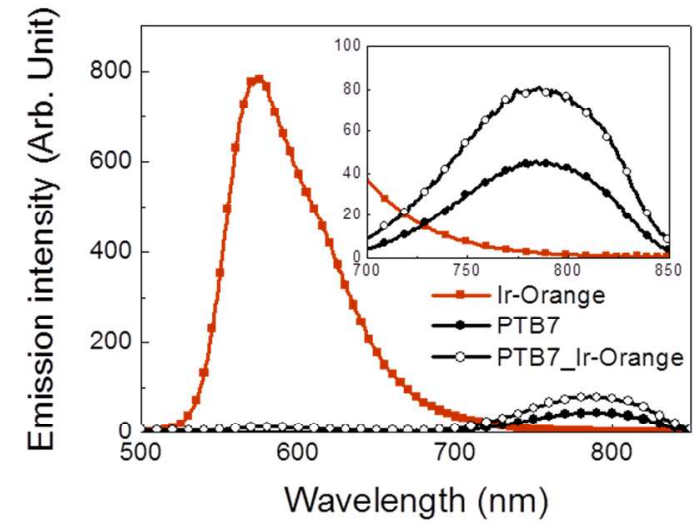

Integrating sphere PL data

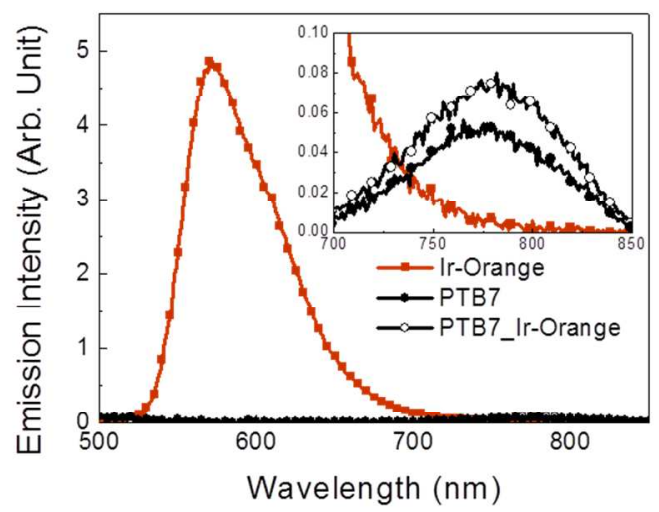

Figure S19-Normal and integrating sphere PL data. The PL data measured with normal and integrating sphere accessories. For the accuracy of PL data, we measured PL spectra with integrating sphere. The shape and trend of two data are well matched with each other. 


\section{Tables}

Table S1-Exciton lifetime and calculated energy transfer efficiency of each $\operatorname{Ir}($ III) complexes with and without PTB7 as an energy acceptor measured by transient PL.

\begin{tabular}{lllll}
\hline & Ir-Red & Ir-Orange & Ir-Green & Ir-Blue \\
\hline Ir(III) complex only & $859 \mathrm{~ns}$ & $1236 \mathrm{~ns}$ & $1466 \mathrm{~ns}$ & $1929 \mathrm{~ns}$ \\
$\begin{array}{l}\text { Ir(III) complex with } \\
\text { PTB7 }\end{array}$ & $9 \mathrm{~ns}$ & $14 \mathrm{~ns}$ & $77 \mathrm{~ns}$ & $90 \mathrm{~ns}$ \\
$\eta_{E T}$ & $99 \%$ & $99 \%$ & $95 \%$ & $95 \%$ \\
\hline
\end{tabular}


Table S2-Summary of device performances with $5 \mathrm{wt} \%, 10 \mathrm{wt} \%$ and $15 \mathrm{wt} \%$ of Ir-Orange.

\begin{tabular}{|c|c|c|c|c|}
\hline Active layer & $J_{S C}\left(\mathrm{mAcm}^{-2}\right)$ & $V_{O C}(\mathbf{V})$ & FF $(\%)$ & PCE (\%) \\
\hline PTB7_Ref. & 13.3 & 0.75 & 71.7 & 7.37 \\
\hline PTB7_Ir-Orange 5wt\% & 15.6 & 0.72 & 71.9 & 8.06 \\
\hline PTB7_Ir-Orange 10wt $\%$ & 16.1 & 0.74 & 72.9 & 8.72 \\
\hline PTB7_Ir-Orange 15wt $\%$ & 16.1 & 0.71 & 71.0 & 8.11 \\
\hline
\end{tabular}

We optimized the amount of the complex Ir-Orange, which showed the highest spectral overlap, for use in the IPSCs and studied different ratios of the Ir(III) complex (5 wt $\%, 10 \mathrm{wt} \%$, and $15 \mathrm{wt} \%$ ) with respect to PTB7. The photocurrent plateaued as the ratio was increased beyond $10 \mathrm{wt} \%$. Therefore, the optimized ratio was determined to be $10 \mathrm{wt} \%$. 
Table S3-Summary of device performances with Orange under $463 \mathrm{~nm}$ and $200 \mathrm{Wm}^{-2}$.

\begin{tabular}{lcccc}
\hline Active layer & $\boldsymbol{J}_{\boldsymbol{S C}}\left(\mathbf{m A c m}^{-2}\right)$ & $\boldsymbol{V}_{\boldsymbol{O}}(\mathrm{V})$ & FF (\%) & PCE (\%) \\
\hline P3HT_Ref. & 5.89 & 0.58 & 50.2 & 8.53 \\
P3HT_Ir-Orange 0.5wt\% & 6.29 & 0.58 & 50.4 & 9.22 \\
\hline
\end{tabular}




\section{References}

1 Nonoyama, M. Benzo[H]Quinolin-10-Yl-N Iridium(Iii) Complexes. Bull. Chem. Soc. Jpn. 1974, 47, 767768.

2 Kwon, T.-H.; Oh, Y. H.; Shin, I.-S.; Hong, J.-I. New Approach toward Fast Response Light-Emitting Electrochemical Cells Based on Neutral Iridium Complexes Via Cation Transport. Adv. Funct. Mater. 2009, 19, 711-717.

3 Wang, J.-L.; Yin, Q.-R.; Miao, J.-S.; Wu, Z.; Chang, Z.-F.; Cao, Y.; Zhang, R.-B.; Wang, J.-Y.; Wu, H.-B.; Cao, Y. Rational Design of Small Molecular Donor for Solution-Processed Organic Photovoltaics with 8.1\% Efficiency and High Fill Factor via Multiple Fluorine Substituents and Thiophene Bridge. Adv. Funct. Mater. 2015, 25, 3514-3523.

4 Lu, L.; Chen, W.; Xu, T.; Yu, L. High-Performance Ternary Blend Polymer Solar Cells Involving Both Energy Transfer and Hole Relay Processes. Nat. Commun. 2015, 6, 7327. 